\title{
Implikasi Upacara Masegeh di Pura Prajapati Desa Pakraman Tambakan pada Penguatan Aspek-Aspek Ekonomi Pariwisata
}

\author{
I Ketut Wardana Yasa \\ Program Studi Penerangan Agama Hindu Fakultas Dharma Duta \\ IHDN Denpasar
}

Email: yasa.wardana@yahoo.com

\begin{abstract}
Human beings have three debts according to the teachings of Hinduism called tri rna and these debt must be paid in his lifetime. Man in debt of God is paid with Dewa Yajña. Humans owe to parents; ancestors are paid with Pitra Yajña. Human in debt with teachers or rsi yajna can be paid by Rsi Yajña. Humans who have debts will try to immediately pay them. Similarly, the debt owned by a person or a family either to his ancestors or to God will always be paid in accordance with their ability through yajña (a sincere sacrifice). Yajna ceremony in the form of masegeh ceremony has an impact on strengthening the aspects of the economy and aspects of tourism development in the Village Pakraman Tambakan.
\end{abstract}

Keywords: Implication, Masegeh Ceremony, Economy, Tourism

\section{Pendahuluan}

Bali merupakan salah satu daerah tujuan wisata internasional yang sangat terkenal di dunia. Sektor kepariwisataan telah menjadi motor penggerak perekonomian dan pembangunan di Bali sejak tahun 1970-an. Oleh karena itu kepariwisataan merupakan bagian yang sangat erat dan tidak dapat dipisahkan lagi dalam kehidupan masyarakat dan pembangunan di Bali. (Pitana, 2003).

Keindahan alam dan kebudayaan Bali yang unik dan beranekaragam yang dituntun atau berpedoman pada falsafah Hindu dan keindahan alam menjadi daya tarik tersendiri bagi para wisatawan, baik wisatawan manca negara, wisatawan domestik maupun wisatawan nusantara. Untuk menjaga keberlanjutan pariwisata di Bali, Pembangunan pariwisata di Bali selalu berdasarkan pada penerapan konsep "Tri Hita Karana". Konsep ini bertujuan untuk menyeimbangkan hubungan antara manusia dengan Tuhan, hubungan manusia dengan manusia, dan hubungan manusia dengan alam. Diharapkan dengan keharmonisan ini, manusia (orang yang tinggal di Bali) dapat memperoleh manfaat dalam bentuk kesejastraan, kemakmuran, kebahagiaan dan kedamaian dalam hidupnya.

Salah satu budaya Bali yang menjadi daya tarik wisatawan adalah berbagai ritual upacara adat dan upacara agama Hindu di Bali, masyarakat Hindu di Bali secara periodik melaksanakan berbagai ritual upacara adat dan keagamaan yang menjadikannya bagian dari kehidupan seharihari masyarakat Bali. Hal ini tentunya akan sangat berpengaruh terhadap perputaran perekonomian masyarakat Bali. Upacara agama menyebabkan modal tidak tertimbun di satu tempat dan membeku, peredaran uang akan cepat dan lapangan kerja akan bertambah akibatnya adalah kemakmuran akan merata. Misalnya orang yang kaya ada kecenderungan untuk memilih melaksanakan upacara utama. Sedangkan kebutuhan upacara kebanyakan hasil produk rakyat kecil seperti sapi, ayam, janur, buah, bunga, alat-alat banten dan peralatan-peralatan lainnya. Mereka akan membeli kepada orang lain yang memiliki perlengkapan tersebut, ini merupakan lapangan kerja bagi masyarakat kecil, dan perputaran roda perekonomian masyarakat.

Sarana-sarana, banten dan peralatan dalam upacara Mesegeh di Pura Prajapati ini dapat dikerjakan oleh orang atau warga desa yang akan melaksanakan upacara, namun ada juga sarana atau bahkan banten yang dibeli dari orang lain. Apabila umat atau keluarga tersebut tidak bisa mengerjakannya maka dapat dibeli pada tukang banten yang sudah biasa mengerjaknnya sehingga dapat juga menjadi lapangan pekerjaan bagi tukang benten (sarati), dan tukang tersebut bisa juga diberikan upah sehingga ada perputaran perekonomian di masyarkat.

\section{Pembahasan}

Upacara Mesegeh di Pura Prajapati ini juga mampu meningkatkan perekonomian masyarakat. Masyarakat Desa Pakraman Tambakan adalah masyarakat yang agraris. Sebagian besar masyarakat bermata pencaharian sebagai petani dan peternak. Binatang sapi sesungguhnya 
tidak bisa dipisahkan dari kehidupan sehari-hari masyarakat Desa Pakraman Tambakan karena sebagian besar dari mereka adalah peternak sapi. Hampir dalam setiap keluarga mereka memiliki ternak sapi bahkan lebih dari satu ekor. Hal ini menjadikan kegiatan masyarakat sehari-hari tidak bisa dilepaskan dari kegiatan yang berhubungan dengan ternak sapi seperti menyabit dan lain sebagainya.

Perekonomian masyarakat Desa Pakraman Tambakan sangat ditunjang dari ternak sapi tersebut. Belakangan telah ada beberapa orang yang berprofesi sebagai saudagar sapi sehingga para peternak dapat menjual sapi-sapi mereka kepada para saudagar tersebut. Ada juga diantara para peternak tersebut yang langsung membawa ternaknya ke pusat jual beli hewan sapi yaitu di Bringkit. Para pemelihara hewan sapi tersebut ada yang memang memiliki sapi sendiri dan ada juga memelihara sapi yang dimiliki oleh orang lain melalui sistem ngadas. Dalam sistem ngadas pemelihara akan memperoleh imbalan setengah dari hasil penjualan setelah dikurangi harga pembelian oleh yang punya hewan sapi tersebut. Dengan adanya penggunaan sapi dalam upacara naur sesangi ini akan ada proses jual beli anak sapi jantan. Bagi umat yang membutuhkan biasanya akan membeli anak sapi jantan tersebut kepada tetangga sehingga dapat membangun perekonomian masyarakat sekitar. Bahkan dari hasil wawancara dengan beberapa informan umat biasanya berkaul akan mempersembahkan anak sapi jantan apabila perekonomian mereka bisa meningkat, misalnya apabila bisa membeli tanah kebun, memiliki ternak yang banyak dan lain sebagainya sehingga dengan demikian umat memiliki sebuah keyakinan dan kepercayaan diri bahwa dengan berkaul dan dengan anugrah dari Bhatara Dalem mereka dapat meningkatkan perekonomian mereka.

Hal lain dalam konteks ekonomi dapat dilihat pula sebagai satu kesatuan sistem unik yang dilakukan oleh warga Desa Pakraman Tambakan. Jadi sisa daging sapi setelah digunakan sebagai sarana upakara Masegeh di bagikan kepada warga, dan sisa tersebut dijual kepada krama desa dan krama lainnya yang dianggap membutuhkan. Sisa dari hasil penjualan tersebut disimpan oleh unsur desa dan akan digunakan dalam upacara dan ritual lainnya, sehingga tidak ada warga sedikit mengeluarkan biaya ketika ada prosesi upacara tertentu. Selain itu, uang khas hasil dari penjualan daging sapi sangat bermanfaat pula dalam pembanguan pisik di pura. Sisa daging I Dewa yang dipersembahkan kemudian dijual dengan harga yang variatif, dan lengkap dengan bukti pembayaran berupa kuintansi.

Krama ngarep dan krama tamiu yang membeli daging I Dewa sisa dari persembahan diberikan bukti pembayaran dan pengolahan uang hasil dari penjualan daging sapi tersebut, ternyata dapat meringankan beban biaya ritual warga Tambakan. Sebagaimana dijelaskan Jero Komang Nita (wawancara,25 Juli 2017) bahwa sapi / I Dewa yang dikurbankan dalam upacara Masegeh lebih dari satu sapi, tetapi yang digunakan hanya satu ekor saja. Oleh karena itu, sisa dari daging sapi yang banyak, dan sisa dari hasil dibagikan (peduman) kepada warga, maka daging sapi dijual kepada warga desa dan warga lainnya dan uang hasil dari penjualan tersebut dijadikan khas desa sehingga bermafaat untuk yajña dan pembangunan desa. Warga percaya kepada pengurus desa sehingga pengelolaan keuangan tidak menggunakan sistem sebagaimana dalam sistem keuangan pada umumnya.

Sistem tradisional tidak saja digunakan dalam prosesi upacara, tetapi dalam hal pengelolaan keuangan pula sistem tradisional digunakan dengan sangat baik. Warga atau krama Desa Pakraman Tambakan tidak mempermasalahkan sistem keuangan, asal pelaporan keuangan sangat jelas disampaikan kepada warga dalam sidang desa atau Pahuman. Warga merasa sangat terbantu dengan sistem tersebut dalam konteks kehidupan sosial. Selain itu, krama pengampel yang merantau dikenakan biaya seratus ribu sehingga desa mendapat penghasilan yang cukup dalam membangun desa dan digunakan ritual upacara, termasuk upacara Masegeh.

Jadi dengan demikian, upacara Masegeh tidak saja membawa implikasi terkait dengan ranah religi, tetapi dalam ranah ekonomi juga membawa penguatan terhadap perekonomian warga desa Tambakan. Pengelolaan uang dengan sistem tradisional merupakan hal yang layak dijadikan temuan dalam kajian ini. Uang hasil dari penjualan daging sapi dibawa oleh prejuru desa dan dikelola dengan swadaya oleh warga setempat, sehingga dibalik gegap gempitanya ritual ekonomi tetap dijadikan basis dalam mensejahterakan diri mereka dalam lingkungan sosial. Selanjutnya, pada prosesi upacara Masegeh berlangsung dari awal hingga akhir, warga yang berprofesi sebagai dagang mendirikan warung darurat disekitar pura untuk melayani warga yang ingin berbelanja. Banyak warung darurat didirikan, dan berdasarkan penuturan salah satu warga yang berdagang, bahwa warung daruratnya bisa menghasilkan lumayan ketika upacara Masegeh dilangsungkan. Hal tersebut menunjukkan bahwa upacara Masegeh tidak saja meningkatkan perekonomian desa secara umum, tetapi perekonomian warga secara personal juga meningkat dengan baik. Warung darurat didirikan di sekitar pura, dan pada warung itu dijual berbagai jenis makan yang dikerumuni warga ketika prosesi upacara Masegeh dilangsungkan, seperti pada gambar 1 berikut. 


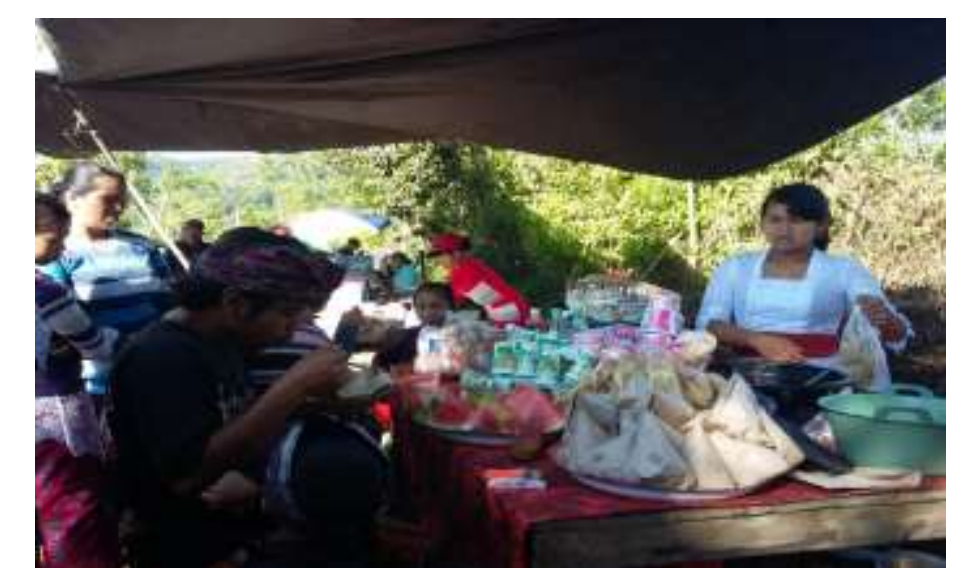

\section{Gambar 1 \\ Warga yang Berjualan dan Mendirikan Warung Darurat Pada saat Upacara Masegeh}

(Sumber: Dokumentasi Wardana Yasa, 2017)

Berdasarkan atas hal tersebut, ekonomi selalu terjadi dalam ranah sosial, dan Bourdiue (2014:40) menjadikan ekonomi sebagai modal dalam postulat teoritiknya karena berhubungan dengan sarana produksi dan pinansial. Modal ekonomi merupakan segenap yang berkenaan dengan pertukaran yang melibatkan si produsen dengan konsumen dalam ranah perdagangan yang bertujuan untuk medapatkan keuntungan. Bagi masyarakat Desa Pakraman Tambakan kebutuhan akan upacara yajña menjadi sangat penting, dan belakangan menjadi komoditi yang efektif bagi kalangan warga untuk medapatkan keuntungan finansial, yakni dengan mengolah daging sapi menjadi makanan dan dijual oleh warga di sekitar desa dan di luar desa. Oleh karena itu, perekonomian warga Desa Pakraman Tambakan selalu ditopang oleh yajna dan senada denga itu Reuter (2005:9) menjelaskan bahwa setiap penyelenggaraan event ritus yajna, bagi masyarkat Hindu desa di Bali sebagian besar menggunakan sarana upakara yang berasal dari sektor pertanian setempat. Namun, kadangkalanya juga dijual dan ditukarkan dengan kebutuhan lainnya. Senanda dengan itu, Korn (dalam Goris, 2013) yang menjelaskan sifat religius masyarakat Bali menentukan seluruh aktivitas; dari hal tersebut munculah kompetensi dalam berbagai bidang kehidupan, baik pertubuhan ekonomi Bali yang cendrung ke arah agraris kultural, dan upacara ritus yajna dijadikan sandaran dalam setiap produksi dan pertukaran. Liefrinck (dalam Goris,2013: 4) juga menyatakan sebagai berikut:

Jadi,tugas utama penduduk desa memerhatikan dewa-dewa, memberikan penghormatan yang diperlukan dan menyajikan bagi mereka sesaji. Dengan demikian, penghormatan harus dijaga dan dipelihara melalui persembahan berupa ritus persembahan. Dalam persembahan masyarakat desa lebih menggunakan sarana yang ada dalam sekitarnya, dan selebihnya ditukarkan dan diperjual belikan dengan sistem ekonomi barang.

Bertolak dari hal tersebut, dapat diketahui bahwasanya perekonomian masyarakat warga Desa Pakraman Tambakan dan Bali dalam konteks kehidupan masyarakat Bali dalam aspek agama sangat sederhana. Bahkan, dalam setiap ritus atau perayaan agama, sistem ngayah dan ngaturang selalu dilakoni sebagai sebuah implementasi ajaran agama, dan bhakti kepada para Dewa. Namun, belakangan perayaan setiap ritus selalu identik dengan pertukaran yang melibatkan si produsen dengan konsumen dalam ranah perdagangan yang bertujuan untuk medapatkan keuntungan. Puspa (2014) menjelaskan bahwa masyarakat Bali masa lalu melaksanakan ritual semakin lama semakin baik karena hubungan kekerabatan maupun sosiologis dengan keluarga maupun masyarakat menjadi sangat berarti. Pada masa itu untuk membuat upakara atau banten dikerjakan dengan anggota masyarakat melalui sistem metulung atau ngoopin.

Namun, pengaruh pembangunan telah merubah kehidupan sosial masyarakat Bali. Budaya ngayah, ngoopin, metulung dan sejenisnya bergeser menjadi budaya modernitas yang lebih menuntut pada kehidupan yang konsumtif. Atmaja (2010:8) menjelaskan bahwa negara berkembang khususnya di Indonesia termasuk Bali pembangunan telah membawa perubahan yang signifikan terhadap kultur masyarakat Bali. Masyarakat yang tradisonal bergeser menjadi masyarakat yang modern dengan memanfaatkan kemajuan dan teknologi. Perubahan pola hidup masyarakat dari agraris ke industri telah mengubah tatanan kehidupan masyarakat Bali. Ideologi masyarakat tradisional Bali yang lebih kepada hal yang bersifat harmonis dan kohisivitas mengalami perubahan akibat dari mengalirnya ideologi dari negara-negara Maju.

Lull (dalam Atmaja,2010: 73) menjelaskan bahwa salah satu bentuk dari ideologi negara maju adalah kapitalisme dan agama pasar. Manusia global memiliki kepercayaan yang sangat kuat 
terhadap agama pasar, dan mendewakan uang serta manusia diperbudak oleh uang dalam agama pasar. Agama pasar sangat cepat memasuki sendi sosial dan budaya, terlebih masyarakat Bali sebagai daerah tujuan pariwisata, dan menjadi ikon wisata dunia. Demikian juga, munculnya para penggila kuasa dari kelas menengah sosial Bali yang menjadi penghubung bagi negara dan modal. Meminjam uraian Suryawan (2012: 3) sebagai berikut:

Kelas menengah sosial Bali menjadi pesulap penggila kuasa yang menjadi penghubung bagi negara dan modal untuk berkolaborasi menguasai jaringan-jaringan ekonomi makro yang meringsek ekonomi rakyat hingga ketitik nadir. Demikian juga birokrat yang memberikan janji atas rekognisi dan tindakan afirmatif terhadap perkembangan ekonomi hanyalah janji ksosong.

Hal tersebut semakin menambah luas ruang agama pasar sehingga sampai pada ranah agama. Agama pasar merangsuk pada aspek agama ditandai dengan adanya polarisasi komodifikasi sarana upakara berupa Banten yang melibatkan pemilik modal simbolik agama dan umat Hindu sebagai pengguna. Komodifikasi banten merupakan salah satu dari dampak pembangunanisme sebagai produksi zaman global, dan agama pasar. Masyarakat Bali banyak yang sudah menganut paham agama pasar, dan memuja uang sebagai yang berkuasa, menjadi homo consumer dengan melakukan ritual sosial ekonomi (Atmaja, 2010: 75). Masyarakat Hindu yang berada dalam trend agama pasar dan modernisasi akan membuat hidupnya senyaman dan semudah mungkin. Bagi penganut paham demikian akan berusaha menjauhkan dirnya dari keruwetan hidup, dan menggunakan modal kapital untuk mempermudah dirinya.

Demikian juga sangat banyak masyarakat Hindu di Bali membeli banten dan menjadikan pula sarana upakara berupa banten dan perlengkapannya menjadi bisnis yang menggiurkan. Banten dan sarana upakara lainnya menjadi komoditi sehingga tidak jarang peluang tersebut dimanfaatkan oleh para Pandita (Sulinggih), dan Griya yang memiliki modal simbolik keagamaan yang mapan. Brahmana yang selama ini diyakini sebagai kalangan elite agama memiliki modal keagamaan sebagai Siwa sekala (Atmaja,2010: 237). Atas kepemilikan modal agama yang dimiliki. Namun yang terjadi di Tambakan sebagian besar upakara dibuat warga dari hasil alam, dan ini menandakan bahwa masih bertahannya ikatan sosial antar warga sehingga kohesivitas warga terjalin dengan baik.

Upacara masegeh juga telah mampu mempengaruhi dan berimplikasi pada penguatan aspek-aspek pariwisata. Di tengah era informasi dan banyaknya warga desa Pakraman Tambakan yang bekerja di bidang pariwisata maka akhirnya upacara ini juga telah menjadi daya tarik wisatawan. Hampir setiap pelaksanaan upacara masegeh selalu dikunjungi oleh wisatawan. Namun sayang masyarakat Desa Pakraman Tambakan belum mengelola potensi ini dengan baik. Kunjungan wisatawan pada upacara masegeh dapat dilihat pada gambar 2 beikut.

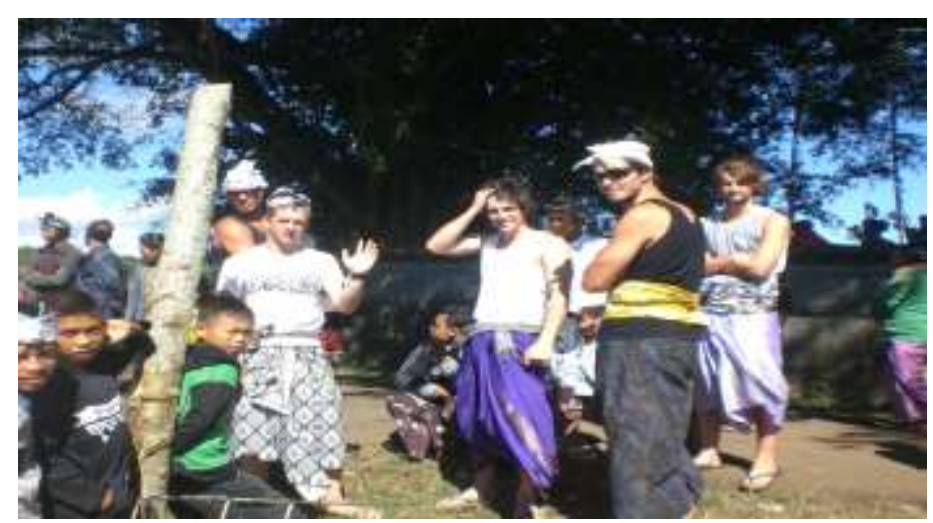

Gambar 2

Kunjungan wisatawan pada upacara masegeh

(Sumber : Dokumentasi Wardana Yasa, 2017)

Interaksi dengan masyarakat lokal serta tradisi dan budayanya merupakan sesuatu yang sangat berharga bagi wisatawan, inilah salah satu alas an mereka berwisata. Begitupun sebaliknya bagi masyarakat local, dapat membangun rasa percaya diri serta bangga terhadap kebudayaan mereka karena tradisi dan budayanya disukai oleh wisatawan. Peran dan interaksi masyarakat lokal terhadap wisata dan wisatawan merupakan nilai tambah bagi pariwisata.

\section{Penutup}

Upacara masegeh telah berimplikasi pada penguatan ekonomi warga dan desa pakraman serta bagi warga yang bergerak di bidang pariwisata. Pendapatan secara langsung bagi warga yang 
berjualan dan warga yang menerima pembayaran atas paket wisata yang dijualnya untuk menyaksikan proses upacara masegeh di Desa Pakraman Tambakan. Pengelolaan perlu dilakukan oleh warga dan desa pakraman tambakan agar dampak ekonomi dari aspek pariwisata dapet lebih ditingkatkan lagi. Kehadiran sektor pariwisata diharapkan dapat memberikan nilai tambah bagi penguatan perekonomian masyarakat setempat, disamping juga sebagai upaya pelestarian nilainilai budaya lokal.

\section{Daftar Pustaka}

Atmaja, Nengah Bawa. 2010. Genealogi Keruntuhan Majapahit Islamisasi, Toleransi dan Pemertahanan Agama Hindu di Bali. Yogyakarta: Pustaka Pelajar.

Goris, R. 2012. Sifat Religius Masyarakat Pedesaan di Bali. Denpasar: Udayana University Press

Korn.C.2013. Sentana di Bali dan Keududukan Waris di Dalamnya. Denpasar: Udayana Press.

Pitana, I Gde. dan Surya Diarta, I Ketut. 2003. Pengantar Ilmu Pariwisata. Yogyakarta : Penerbit Andi.

Reuter, Thomas A. 2005. Custodians of the sacred mountains Budayadan Masyarakat di pegunungan Bali. Jakarta: YayasanObor Indonesia.

Yoeti, Oka A. 1996. Pengantar Ilmu Pariwisata. Bandung: Angkasa 2008. Perencanaan dan Pengembangan Pariwisata. Jakarta: PT. Pradnya Paramita. 